\title{
1
}

\section{Child Protection and Human Rights: A Call for Professional Practice and Policy}

\section{Asgeir Falch-Eriksen and Elisabeth Backe-Hansen}

\section{Introduction}

Professional practice is a defining trait of modernity, and democratic and constitutional nation-states depend on professional practitioners and their efforts to solve problems and coordinate activity in order to distribute state services as accurately as possible, thus dealing with the particular problem at hand of implementing human rights. Throughout modern history, legislators in different democratic nation-states have developed complex systems of implementation to make sure that public resources are distributed at the street level according to their democratic intent, and in an accurate manner aimed at solving particular problems. In this manner, state services at the street level are provided according to predetermined political and legal distributive standards set by elected officials through regular law-making and constitutional rights norms. Consequently, professional practice is a cen-

\footnotetext{
A. Falch-Eriksen $(\bowtie) \bullet$ E. Backe-Hansen

Norwegian Social Research, Oslo Metropolitan University, Oslo, Norway e-mail: asgeirer@oslomet.no; ebha@oslomet.no 
tral tool in the democratic chain of command in the efforts of legislators to implement democratic policies, and to distribute public goods and burdens. This is also the case with regard to child protection services. Within the system of child protection there are countless practitioners who must abide by the law.

During its nearly thirty years of existence the United Nations Convention on the Rights of the Child (CRC) has become not only an international human rights convention, but also a catalogue of rights that expresses legal norms used by legislators to legitimize systems of child protection. The convention has been embraced across nation-states globally, and by legislators who claim to push for a legal development on a par with the normative ethos of the CRC. Hence, by now the CRC is not just a banner, but a toolkit that expresses a normative order, that is, a human rights standard for how to legitimately protect children. Such a standard, which we will return to throughout the book, attempts to capture the underlying normative ethos of human rights and the indivisibility of rights. Incrementally, the CRC has become a point of reference in developing child protection services, as a way to design decision-making procedures, understand what constitutes the child's integrity, and develop professional practice and policy. This potential is what the book sets out to explore.

\section{The Aim and Scope of the Book}

The main aim of the book is to utilize a human rights standard as a prism, and critically explore what implications human rights have for professional practice and public policy. In this way, the book will explore and utilize a normatively substantial and conceptually rich analytical approach to practices of child protection. Child protection services have deep roots as public services across many modern nation-states (Fox Harding 2014), and they all depend on case workers at street level. Although there are significant variations across nation-states, in recent history most child protection services are bound to argue that they respect, abide by and enforce the CRC. Variations exist as to: what public sector the services belong to; what and how legal rules set the design for child protection 
services; what interventions are allowed, their frequency, and what measures could be used; how attached services are to education, healthand social services; what type of budgetary priority services are given; and so forth. Rights, on the other hand, are equalizers across nation-states, although they too are open to variation.

This book will transcend nation-bound rhetoric, albeit predominantly referencing nation-based empirical research to anchor discussions in the normative-political development that gradually points in the direction of increasingly implementing the CRC across policy and professional practice. Hence, child protection services are developing towards a widely shared human rights standard across nation-states, which explicitly grant children the right to protection (cf. CRC Art. 19). The CRC constitutes a rights-based normative order that has increasingly infused law-making across the world, and in some nation-states become formal law and even constitutional law.

Through CRC Art. 19.1, every child is provided the right to protection:

States Parties shall take all appropriate legislative, administrative, social and educational measures to protect the child from all forms of physical or mental violence, injury or abuse, neglect or negligent treatment, maltreatment or exploitation, including sexual abuse, while in the care of parent(s), legal guardian(s) or any other person who has the care of the child.

This right can be claimed by any child living within a jurisdiction claiming to abide by the CRC. However, how or whether it will be answered will vary. Although an international human rights standard has gradually become a source for legitimizing the public protection of children, this does not preclude certain strands of politics opposing rights-based protection. Still, rights-based protection has increasingly become a source of reference and a standard to strive for across the globe (Gilbert et al. 2011).

If a child is maltreated, a rights-based public protection of children will enter in loco parentis, in the place of the parent, and intervene to sustain the child's personal integrity and aid the child's development. Maltreatment, caused by the violence or neglect of care-givers to the detriment of the child, must lead to interventions proportionally to the needs of the child. 


\section{$3 \quad$ 'Lady Justice' at Street Level}

'Lady Justice' is the personification of rule-of-law and an important symbol as to what merits the legitimate application of legal rules. She holds a sword in one hand and a scale in the other, and she carries a blindfold. Her face shows no significant expression. Rule-of-law is symbolized as blind because every subject under the law is to be treated equally when equal, and unequally when unequal. This is referred to as the formal principle of equality and is best summed up by the catch-phrase 'equality before the law'. The scale symbolizes a transparent process of reasoning, which ensures that each citizen is judged both according to general and known laws but also valid laws. Art. 7 of the Universal Declaration of Human Rights stipulates that 'All are equal before the law and are entitled without any discrimination to equal protection of the law.' Art. 7 is traceable to the constitutional traditions of the USA and France, and has its modern roots particularly in John Locke and its classical roots in Aristotle's Politics (Aristotle 2014). The CRC has its equivalent in Art. 2-the child's right to not suffer discrimination of any kind.

Justice is not merely a formal precept for equal treatment, but also equal treatment according to legal rules, and therefore the normative and political intent of those rules. Consequently, if rule-of-law is to work, 'Lady Justice's' judgments cannot be in conflict with legal rules, nor with their normative and political intent. If we turn to modern democratic and constitutional nation-states, which all enforce some version of a principle of rule-of-law, 'Lady Justice' must also enforce democratically forged rules. Popular sovereignty thereby becomes embedded into her judgments and judgments become parasitic upon the legitimacy of democracy. In this way, whenever a democratic nation-state passes new rules, she rules accordingly. Finally, 'Lady Justice' carries a sword that symbolizes coercion. The sword is the threat of sanctions whenever there is a breach of the law, and cannot be wielded without the authority of the law.

As already noted, in modern and complex nation-states, enforcement of legal rules often depends on professional practitioners at street level (Lipsky 1980). Legislators do not have the competence, the time or desire to provide the necessary quality of services in every conceivable case that 
confronts the modern nation-state on which its citizens depends. Legislators thus need to shape decision-making processes, jurisdictions and organizations in such a way that professional practitioners can handle any type of case within their remit. The legislature authorizes professional practitioners at street level through rule-of-law, enabling them to make decisions locally in each case by providing practitioners the mandate to reach decisions. This involves granting practitioners autonomy to reach decisions in specific cases by way of a public mandate. In this manner, we can describe the practitioners as a street-level version of 'Lady Justice'.

\section{Child Protection and Discretion}

Those who become authorized to work as 'Lady Justice' in child protection are case-workers in child protection services. They are professional practitioners set to become part of the democratic chain of command as implementation agents of politics, and in their capacity as case-workers they enforce the law and become its final arbiters at street level (Molander et al. 2012; Rothstein 1998). When case-workers enforce the law, they have been delegated the authority to exercise discretion. This is what Robert Goodin characterizes as the positive aspect of discretion, namely that a case-worker 'can be said to have discretion if and only if he is empowered to pursue some social goal(s) in the context of individual cases in such a way as he judges to be best calculated' (1986). A caseworker who departs from pursuing social goals is on the other hand not enforcing her or his delegated authority in any legitimate manner. In the public sector the social goal is provided as a democratic mandate, especially through legal rules, budgets and administrative directives. This is also where the CRC becomes relevant-namely in that practices that are argued by legislators are supposed to follow the CRC and become mandated through the democratic will to enforce the human rights standard underpinning the $\mathrm{CRC}$, and thus cannot depart from the convention. If practice departs from the human rights standard, it will become challenging to defend a practice as legitimate either according to a principle of democracy or a human rights standard. 
A delegation of authority to street level implies that case-workers must reach decisions that are neither in conflict with the law nor in breach of the intention of the law. While the former is a formal and structural restriction where case-workers are obligated to justify decisions, the latter is mainly epistemic and left to the autonomous capabilities of the caseworker. The autonomy of case-workers implies that case-workers must be able to reach decisions and justify them in accordance with a type of knowledge that preserves the intention of the law and the delegated authority (Molander et al. 2012). To this end, Goodin also provides a negative characterization of discretion, encapsulating what can be referred to as epistemic autonomy. Goodin alludes to the fact that discretion does not make sense if it denotes a complete freedom of choice, that is untethered autonomy. Hence, discretionary competence, conveyed by a caseworker, is always in accordance with certain restrictions.

Case-workers in child protection must reach decisions that are in accordance with the restrictions set by the law, and more specifically the CRC. They must practice their autonomy according to not just the letter of the law, but also the normative intent of the law. Goodin refers to this area of autonomy as 'a lacuna in a system of rules'. This aspect of discretion refers to an area 'which is generally governed by rules, but where the dictates of the rules are indeterminate' (Goodin 1986). The authorization of case-workers constitutes the delegation of authority to reach decisions autonomously, but supposedly predictably according to the intention of the law.

\section{Human Rights and the Right to Protection}

Basic to a human rights standard and a theory of rights are the notion of individual liberty and the corresponding absence of, and protection against, unlawful and arbitrary domination. This type of normative underpinning can be traced back to the classic liberal views especially of John Locke and Immanuel Kant. Both scholars promulgated a philosophy of individual freedom through constitutional protection, that is through rights, and with a strict impersonal principle of law especially 
underpinned by the principle stipulating the individual's equality before the law and non-discrimination. Operative expressions of constitutionalism carrying the ideas of Locke and Kant can be found in the preambles to the constitutions in both France and the USA. The principle of individual liberty rings heavily in modern nation-states and in efforts to implement, maintain and enforce human rights. In order for human rights to have any purposeful function, they need to be constitutional to other types of regulation and become universally applied to all who carry citizenships (see Chap. 3 for further elaboration). An important lesson from the liberal doctrine is that it constrains popular will and curbs the manner in which popular sovereignty works, what legal rules can pass, how public regulation and policy are performed and how public services are offered at street level through professional practice.

Particularly since the end of the Second World War, human rights have become embedded in state-constructs across the world, particularly where upholding the personal integrity of each individual person has become a hallmark. The development has firmly established the liberal constitutional democracy as an organizational norm which is optimal for introducing, maintaining and enforcing human rights. How such an organizational norm becomes operationalized, through what type of democracy and what type of constitutionality, nevertheless varies between nation-states.

Abiding by human rights, by enforcing a human rights standard that upholds the indivisibility of rights in all relevant matters, will have enormous consequences for the designs of activities in a nation-state, its regulations, organizations and use of knowledge. However, rights must actively be infused by lawmakers, bureaucrats and professionals through implementation and enforcement, in each and all actions relevant to collective problems-solving and coordination. In all relevant aspects of democratic rule-of-law, the respect of the integrity of each individual as a matter of human rights must be coherent and visible. By this way of thinking, modern state-constructs that lay claim to abide by human rights must let a system of rights become constitutive of any state activity in the sense that one can clearly trace the system of rights and explain how the state works by referring to rights. 


\section{$6 \quad$ Child Protection as a Public and Professional Service}

Child protection is a public service aimed at protecting children against detrimental care, that is different types of maltreatment (Kriz and Skivenes 2014). Services are typically more rule-governed in the most intrusive cases where child protection services coercively remove children from their home. This means that on the one hand, the scope of what we above referred to as negative discretion, in cases involving coercion, is very narrow (see Burns et al. 2016). So-called in-house measures, on the other hand, where parents' and children's rights to privacy and family life are not infringed on in a significant manner, are typically less rulegoverned. Through in-house measures, then, the case-worker has more scope to reach autonomous decisions, and has more responsibility to enforce the rights of the child. In areas where case-workers' autonomy is wide-ranging, their application of epistemic autonomy makes them more directly accountable.

However, both of types of interventions are structurally and epistemologically rule-governed practices of discretion. As the case-workers at street level meet families and children who need assistance or protection, the actions they can initiate are directly linked to the mandate they have through the delegation of authority. Once this area of discretion is structurally established through law-making, the decisional autonomy of the case-worker, or in Goodin's words, the 'lacuna in a system of rules', is the jurisdiction to which professions lay claim to provide the best-practice norms within the scope of negative discretion (Abbott 1988; Goodin 1986). It is in the lacuna of the system of rules that the case-workers of child protection take on the traits of what we have discussed earlier as the street-level 'Lady Justice'.

Although child protection services across modern nation-states are organized in different ways, many refer to the CRC as a legitimating force. In this way, the CRC becomes a legal framework to justify decision-making, policy development, organizational designs and regular law-making (see e.g. Skivenes and Sørsdal 2018: Chap. 4 in this book). The need for professionalization of child protection has grown 
out of the legislator's need to rely on knowledge-based practice within its services to fulfil its tasks in collective problem-solving and collective coordination. The push for increasing professionalization is driven by the development in knowledge about how best to protect children, but as well by more advanced professional educators and practitioners, those who receive services, and finally the democratic will embedded in the legislators pushing to provide certain types of protection and not others.

When children are subjected to varying degrees of maltreatment by their care-takers, they need protection. The state, as the only entity to exercise legitimate coercion, then has the legitimacy to intervene as long as it can be justified that the intervention is in the child's best interests (cf. CRC Art. 3).

In increasingly pluralistic and complex nation-state systems, adequate and knowledge-based interventions in child protection-cases cannot just be directed top-down, or decided on in advance, if the rights of the child are to be enforced. Thus, each decision needs to be made according to individual interests, needs and preferences. Case-workers needs to assess each particular child's care context, comprehend all relevant facets and act on the concrete distribution of resources to amend any maltreatment that the child is subjected to. Thus, each professional is delegated the authority and instructed to define what the problem at hand is, and then to give an independent evaluation of what is required to solve the particular problem (Goodin 1986).

\section{Contents of the Book}

In Chap. 2, Kirsten Sandberg explains and explores the right to protection as it is embedded in CRC Art. 19. The chapter provides a legal understanding of the child's right to protection against maltreatment by care-takers, and it also explores the obligations of states parties in implementing the right to protection in professional practice and in policy. The rights and obligations form the framework within which to exercise professional judgment in the area of child protection, and specifying their 
content is a prerequisite for rights to be realized. The focus is on the obligations to prevent and respond to maltreatment as well as on the best interests of the child.

In Chap. 3, Asgeir Falch-Eriksen explains what human rights entail for professional practice. The chapter elaborates theoretically and analytically using a counterfactual, namely that human rights, and in particular the CRC, is a standard point of reference for professional practitioners and practices within and across nation-state systems of child protection. The chapter elaborates on how rights challenge professional practice, and how to best answer some of these challenges. It especially focuses upon how to understand the child's right to liberty once adulthood kicks in, and how development must be carefully plotted out to maintain the integrity of the person through to adulthood.

In Chap. 4, Marit Skivenes and Line Marie Sørsdal discuss how the rights of the child are operative in legislation across nation-states. The chapter studies how governments have a range of steering mechanisms and incentives to guide and rein in professional use of discretion in decision-making. In their study, they examine how governments set a standard for decision-making about the best interests of the child in intrusive interventions. The empirical focus is the formulation of the principle of the child's best interest in child protection legislation in 14 countries.

In Chap. 5, Eileen Munro and Andrew Turnell illustrate the way the role of professionals is constructed within an organization, and how the design of such organizations helps or hinders them. They will use England as an example that illustrates the range of organizational change that has been needed both to allow and also to support rights-based practice.

In Chap. 6, Tarja Pösö discusses how Art. 12 of the CRC, which is the child's right to participation, is operative through organizations of predominantly children with experience from child protection services, socalled 'experts by experience'. The chapter discusses how their messages influence child welfare policy and practice. The focus is on one particular Finnish group of experts by experience, and its immense impact on policy and practice.

In Chap. 7, Anne-Dorthe Hestbæk examines the rights of young people in out-of-home care. The chapter utilizes five articles in CRC as a 
lever to critically assess whether or not they are operative in professional practice. The chapter highlights, for example, participation, protection against harm, and whether or not children feel cared for or loved. The chapter reaffirms the findings that young people being placed in institutional care seem to live under considerably more disadvantaged conditions than young people in foster care.

In Chap. 8, Elisabeth Gording-Stang problematizes practices of emergency cases in child protection, and how child protection services sometimes must intervene without traditional legal safeguards. She uses court decisions to shed light on how fundamental contradicting interests are being considered and balanced by the courts, and how professional practice at the street level may learn from it.

In Chap. 9, Bente Kojan and Graham Clifford discuss whether the avowed aim of a preventative approach in child protection, with strategies that set out to avoid the very large moral and economic costs of placement outside the family, is at all well served by the prevailing distribution of child protection assistance to families and children. They discuss how rights-based, professional child protection work might be of help.

In Chap. 10, Øivin Christiansen and Ragnhild Hollekim discuss how principles of the CRC inform and challenge the practices of professionals engaged in child welfare services' preventive in-home measures. The discussion centres on the threefold relationship between the child, the parents and the state. They question where to place the threshold for public intervention in family life, and how to realize children's rights to services when their parents do not give their consent. They further discuss reasons for and consequences following the fact that support to children is primarily strived for through targeting parents. Finally, the chapter problematizes three possible consequences: the homogenization of parenthood, reduction of complexity and the marginalization of children themselves.

In Chap. 11, Cecilie Basberg Neumann draws attention to the meaning of social workers' conduct of care practices with young children living in residential child protection institutions. She is interested in identifying what good care practices may be, and to discuss how these practices may be understood as realizations of CRC Art. 3, on the best interests of the child. Through observations and articulations of what social workers do 
when they provide care for children in residential institutions, she attempts to show that good care practices for young children have a lot to do with the social worker's willingness to engage in sensitive, responsible and embodied interactions with the children.

In Chap. 12, Elisabeth Backe-Hansen focuses on CRC Art. 12 as it pertains to foster children. In addition to participation rights that all children share, foster children have a set of administrative participation rights related to their case. Foster parents have to share their parental authority with persons of authority outside of the family. In contrast, she discusses children's participation in everyday decision-making as an integral part of family life, and what challenges may occur when foster children and other children with participatory rights must interact.

The concluding chapter summarizes the main findings and discusses their interconnection.

\section{Conclusion}

We are living in a time when systems of child protection across modern nation-states receive massive criticism both nationally and internationally. In particular, this pertains to out-of-home placements of children, against parents' expressed wishes. Voluntary in-house measures are mostly ignored in this context. Different nation-states' politicians, public officials, NGOs, professionals, scholars, the traditional and new media, all participate in these discussions, from various points of departure. Since child protection is characterized by controversy as well as being an academic field submerged in normative complexity and uncertainty, answers and heated discourses about what constitutes 'the best' type of protection abound.

However, rights are an equalizer, and children living in jurisdictions that claim to abide by rights should not experience widely different practices if said practices are supposed to abide by the same framework of legislation. Although there are widely different ways to perform child protection services, the CRC provides us for the time being a common goal. 


\section{References}

Abbott, A. (1988). The system of professions. An essay on the division of expert labor. Chicago: University of Chicago Press.

Aristotle. (2014). Politics. In J. Barnes (Ed.), The complete works of Aristotle: The revised Oxford translation, one-volume digital edition. Princeton: Princeton University Press.

Burns, K., Pösö, T., \& Skivenes, M. (2016). Child welfare removals by the state. A cross-country analysis of decision-making systems. New York: Oxford University Press.

Fox Harding, L. (2014). Perspectives in child care policy. London: Routledge.

Gilbert, N., Parton, N., \& Skivenes, M. (2011). Child protection systems: International trends and orientations. New York: Oxford University Press.

Goodin, R. E. (1986). Welfare, rights and discretion. Oxford Journal of Legal Studies, 6(2), 232-261.

Kriz, K., \& Skivenes, M. (2014). Street-level policy aims of child welfare workers in England, Norway and the United States: An exploratory study. Children and Youth Services Review, 40, 71-78.

Lipsky, M. (1980). Street-level bureaucracy. Dilemmas of the individual in public services. New York: Russell Sage Foundation.

Molander, A., Grimen, H., \& Eriksen, E. O. (2012). Professional discretion and accountability in the welfare state. Journal of Applied Philosophy, 29(3), 214-230. https://doi.org/10.1111/j.1468-5930.2012.00564.x.

Rothstein, B. (1998). Just institutions matter. The moral and political logic of the universal welfare state. Cambridge: Cambridge University Press.

Skivenes, M., \& Sørsdal, L. M. (2018). The child's best interest principle across child protection jurisdictions. In A. Falch-Eriksen \& E. Backe-Hansen (Eds.), Human rights in child protection. Implications for professional practice and policy. London: Palgrave Macmillan. 
Open Access This chapter is licensed under the terms of the Creative Commons Attribution 4.0 International License (http://creativecommons.org/licenses/ by/4.0/), which permits use, sharing, adaptation, distribution and reproduction in any medium or format, as long as you give appropriate credit to the original author(s) and the source, provide a link to the Creative Commons license and indicate if changes were made.

The images or other third party material in this chapter are included in the chapter's Creative Commons license, unless indicated otherwise in a credit line to the material. If material is not included in the chapter's Creative Commons license and your intended use is not permitted by statutory regulation or exceeds the permitted use, you will need to obtain permission directly from the copyright holder.

(c) 